\title{
Latitude- and climate-associated patterns in small mammal fauna changes of the West Yakutia
}

\author{
Yakov L. Volpert \& Elena G. Shadrina*
}

\begin{abstract}
Distribution of small mammals has been analyzed on the territory of the Western Yakutia in the corridor between $112^{\circ}$ and $116^{\circ} \mathrm{E}$ and between the Lena River valley (starting from the Vitim River mouth) and the Anabar and Olenyok interriverine area $\left(59-71^{\circ} \mathrm{N}\right)$. The material was collected in 2002-2017 in 11 sites within the taiga zone (from the border between the middle and south taiga to the northern border of the north taiga subzone). A total of 11200 cone-days and 12500 trap-days were accumulated and 4200 specimens of small mammals belonging to 21 species were collected. The highest species richness of small mammals is registered on the border of the south and middle taiga (17-18 species). In the north taiga the fauna of small mammals is represented by 8-9 species. This decrease from south to north is uneven: in the river valleys the species richness is generally higher than in the watersheds. The penetration of taiga species to the north is of a larger scale than that of tundra species into taiga habitats; therefore, changes in beta-diversity occur mainly due to the distribution limits of boreal species. Besides, in the absence of geographic barriers, a sharp decline in species richness is observed between $65^{\circ}$ and $66^{\circ} \mathrm{N}$, which coincides with the boundary between the middle-taiga and north-taiga subzones. Out of the climatic factors, the distribution of small mammals is affected mainly by winter precipitation, winter duration, average July temperature and average annual temperature, while dependence on such factors as January temperature and summer precipitation was not found.
\end{abstract}

How to cite this article: Volpert Y.L., Shadrina E.G. 2019. Latitude- and climate-associated patterns in small mammal fauna changes of the West Yakutia // Russian J. Theriol. Vol.18. No 2. P.99-106. doi: 10.15298/rusjtheriol.18.2.04

KEY WORDS: small mammals, species diversity, fauna, latitudinal gradient, climatic factors, Yakutia.

Yakov L. Volpert [ylv52@mail.ru], Research Institute of Applied Ecology of the North-Eastern Federal University, Lenin avenue 1, Yakutsk 677000, Russia; Elena G. Shadrina [e-shadrina@yandex.ru], Institute for Biological Problems of Cryolithozone, Siberian Branch of the Russian Academy of Sciences, Federal Research Center "Yakutian Scientific Center SB RAS”, Lenin avenue 41, Yakutsk 677980, Russia.

\section{Широтно-климатические закономерности изменения фауны мелких млекопитающих Западной Якутии}

\section{Я.Л. Вольперт, Е.Г. Шадрина}

РЕЗЮМЕ. Проанализировано распространение мелких млекопитающих на территории Западной Якутии в коридоре $112-116^{\circ}$ в.д., в направлении с юга от долины р. Лена в районе устья р. Витим на север до Оленек-Анабарского междуречья (59-71 с.ш.). Материал собран в 2002-2017 гг. в 11 точках в пределах таежной зоны (от границы средней и южной тайги до северной границы северотаежной подзоны). Отработано 11200 конусо-суток, 12500 давилко-суток и отловлено 4200 представителей мелких млекопитающих, относящихся к 21 виду. Наиболее высокое видовое богатство мелких млекопитающих отмечено на границе южной и средней тайги (17-18 видов). В северной тайге фауна мелких млекопитающих представлена 8-9 видами. Обеднение фауны в направлении с юга на север происходит неравномерно: в долинах рек, как правило, видовое богатство выше, чем на водоразделах. При этом проникновение таежных видов на север носит более масштабный характер, чем тундровых - в таежные местообитания, поэтому изменения бета-разнообразия здесь происходят в основном за счет границ распространения бореальных видов. Кроме того, при отсутствии географических преград резкое снижение видового богатства наблюдается в интервале $65-66^{\circ}$ с.ш., что совпадает с границей между среднетаежной и северотаежной подзонами. Среди климатических факторов на распространение мелких млекопитающих основное лимитирующие влияние оказывают количество зимних осадков, длительность зимнего периода, средняя температура июля и среднегодовая температура, в то же время зависимости от таких факторов как температура января, и количество летних осадков не выявлено.

КЛЮЧЕВЫЕ СЛОВА: мелкие млекопитающие, видовое богатство, фауна, широтный градиент, климатические факторы, Якутия.

* Corresponding author. 


\section{Introduction}

Studies of biological diversity at different levels of ecosystem organization are of apparent interest, not only from a theoretical point of view, but also for making decisions in the field of environment protection and biodiversity conservation (Kullberg \& Moilanen, 2014). The latitudinal gradient of decreasing diversity of animals and plants from tropical to extratropical regions is a well-known fact (Odum, 1983), while the reasons determining species richness are still subject to debate. There are many hypotheses that are trying to explain the latitudinal changes in species richness and functional diversity by evolutionary and environmental factors, interspecific interactions, and availability of food resources (Pianka, 1966, 1978; Rohde, 1992; Buckley et al., 2010; Fraser et al., 2014; Lamanna et al., 2014; Fergnani \& Ruggiero, 2015; Schemske \& Mittelbach, 2017; Willig \& Presley, 2018). According to many authors, the leading role in the manifestation of the latitudinal gradient of species richness is played by climatic factors (Andrews \& O'Brien, 2000; Willig et al., 2003; Moreno-Rueda \& Pizarro, 2009; Qian et al., 2009; Oliveira et al., 2016; Brodie, 2019), it was also noted that the influence is more pronounced for extratropical latitudes (Qian et al., 2009; Fergnani \& Ruggiero, 2017), and that for animals these changes are governed by both climatic factors per se and indirectly, through changes in the plant species richness (Andrews \& O’Brien, 2000).

In the recent decades, interest in assessment of biological diversity has increased due to the increased anthropogenic impact against the background of global climate change. Many authors note that one of the important specifics of the Anthropocene of the 21st century is the decrease in biological diversity (Pereira et al., 2010; Kullberg \& Moilanen, 2014). This is an environmental problem that can have serious consequences for humanity in the near future (Kullberg \& Moilanen, 2014). Global climate change is expected to increase the rate and risk of species extinction (Urban, 2015). According to a number of authors this will result in the shift of the northern boundaries of geographic ranges, and consequently, in the increased extinction rate of inhabitants of high latitudes (Murphy \& Weiss, 1992; Kerr \& Packer, 1998).

It is worth noting that the species richness of mammals is researched unevenly: while gamma-diversity of vertebrate faunas is analyzed in sufficient detail, beta-diversity, especially in the northern regions, is explored not as good. Many areas of North-East Asia are still studied poorly even at the level of alpha diversity, and because of the poorly developed transport network and inaccessibility of many areas, the analysis of beta-diversity is often limited to the valleys of large rivers. There are data on changes in the composition of insectivore communities (Sheftel, 1983) and mouse-like rodents (Sapogov, 1983) in the valley of the Yenisei River, changes in the fauna of small mammals of the Lena River valley (Volpert \& Yudin, 1986); regional zoning of the territory of south-eastern Transbaikalia was conducted (Obolenskaya \& Lissovsky, 2015).
On the territory of Yakutia, almost all sites of small mammal research are confined to the valleys of large rivers. This circumstance leaves a certain mark on the picture of the species distribution across the territory, since the role of river valleys as environmental corridors is widely known. Without any doubt, this circumstance was reflected in the results of the analysis of the specifics of species distribution across the territory of Yakutia (Tavrovskij et al., 1971; Krivosheev, 1973; Mordosov \& Vinokurov, 1980; Mordosov, 1987, 2014; Volpert \& Shadrina, 2002). A comparative faunistic analysis of small mammals in the studied territory in the latitudinal gradient outside the valleys of large rivers has not previously been carried out.

The goal of our research was to assess the changes in the species richness of small mammals of taiga ecosystems of the North-East Asia in the latitudinal gradient by the example of West Yakutia. The territory of Sakha (Yakutia) Republic covers two geographic zones and due to this fact alone it would be of interest for analysis of the latitudinal distribution of animals, in particular, small mammals. In addition, the distribution boundaries of many species of small mammals go across the territory of Yakutia, which gives the studies of the patterns of distribution of animals additional significance.

\section{Material and methods}

The data of 15 years of research of small mammal fauna are summarized, with sites geographically distributed not along the river valleys, as previously (Volpert $\&$ Yudin, 1986), but in the corridor between $112^{\circ}$ and $116^{\circ} \mathrm{E}$ and from the Lena River valley (near the mouth of the Vitim River, $59^{\circ} \mathrm{N}$ ) in the south to the Olenyok and Anabar interriverine area in the north $\left(71^{\circ} \mathrm{N}\right)$.

Material for this work was collected in 2002-2017. From south to north, the sites where small mammals were collected are arranged in ascending order from 1 to 11 (Table 1, Fig. 1). In these sites 11200 cone-day, 12500 trap-days, and 4200 specimens of small mammals belonging to 21 species were collected.

The standard methods for studying the population of this group were used: grooves with cone traps and breakback traps with standard bait (Kucheruk, 1963; Karaseva \& Telitsyna, 1995). This combination ensures, in our opinion and according to other authors (Shchipanov et al., 2010), the most complete coverage of small mammal population. Comparison of the community compositions was carried out using the Jaccard index and the analysis of the influence of climatic parameters was performed using nonparametric statistics (Spearman's rank correlation coefficient). For assessment of the effect of the climate we used average long-term data of the Russian Meteorological Service. The following parameters were considered: winter duration (from the onset of the permanent snow cover to its melting); summer, winter, and annual precipitation; average temperatures: annual, the warmest month (July), and the coldest month (January). Climate influence was assessed in six sites $(2,3,7,8,9$, and 11), for which the data from weather stations could be extrapolated. 
Table 1. Research sites on the territory of the West Yakutia in the corridor $112-116^{\circ} \mathrm{N}$.

\begin{tabular}{|c|l|l|c|}
\hline No. & \multicolumn{1}{|c|}{ Name } & \multicolumn{1}{c|}{ Geography } & \multicolumn{1}{c|}{ Coordinates } \\
\hline 1 & Vitim \& Lena right bank & The right bank of the Lena River and the mouth of the Vitim River & $59^{\circ} 25^{\prime} \mathrm{N}, 112^{\circ} \mathrm{E}$ \\
\hline 2 & Lena left bank & The left bank of the Lena River & $59^{\circ} 25^{\prime} \mathrm{N}, 112^{\circ} \mathrm{E}$ \\
\hline 3 & Peleduy & The Peleduy River valley & $59^{\circ} 43^{\prime} \mathrm{N}, 112^{\circ} \mathrm{E}$ \\
\hline 4 & Nyuya \& Peleduy IA* & The Nyuya and Peleduy rivers interriverine area & $59^{\circ} 54^{\prime} \mathrm{N}, 112^{\circ} \mathrm{E}$ \\
\hline 5 & Nyuya & The Nyuya River valley & $60^{\circ} 20^{\prime} \mathrm{N}, 112^{\circ} \mathrm{E}$ \\
\hline 6 & Taas-Uryakh & Tas-Uryakh vicinity & $61^{\circ} 43^{\prime} \mathrm{N}, 112^{\circ} \mathrm{E}$ \\
\hline 7 & Mirny & Mirny vicinity & $62^{\circ} 31^{\prime} \mathrm{N}, 113^{\circ} 53^{\prime} \mathrm{E}$ \\
\hline 8 & Vilyuy & The Vilyuy River valley & $62^{\circ} 03^{\prime} \mathrm{N}, 116^{\circ} 54^{\prime} \mathrm{E}$ \\
\hline 9 & Udachny & Udachny vicinity & $66^{\circ} 28^{\prime} \mathrm{N}, 112^{\circ} \mathrm{E}$ \\
\hline 10 & Muna & The Muna River valley(a right tributary of the Lena River) & $67^{\circ} 15^{\prime} \mathrm{N}, 114^{\circ} \mathrm{E}$ \\
\hline 11 & Olenyok \& Anabar IA & The Olenyok and Anabar rivers interriverine area & $71^{\circ} 02^{\prime} \mathrm{N}, 116^{\circ} \mathrm{E}$ \\
\hline
\end{tabular}

* IA - interriverine area.

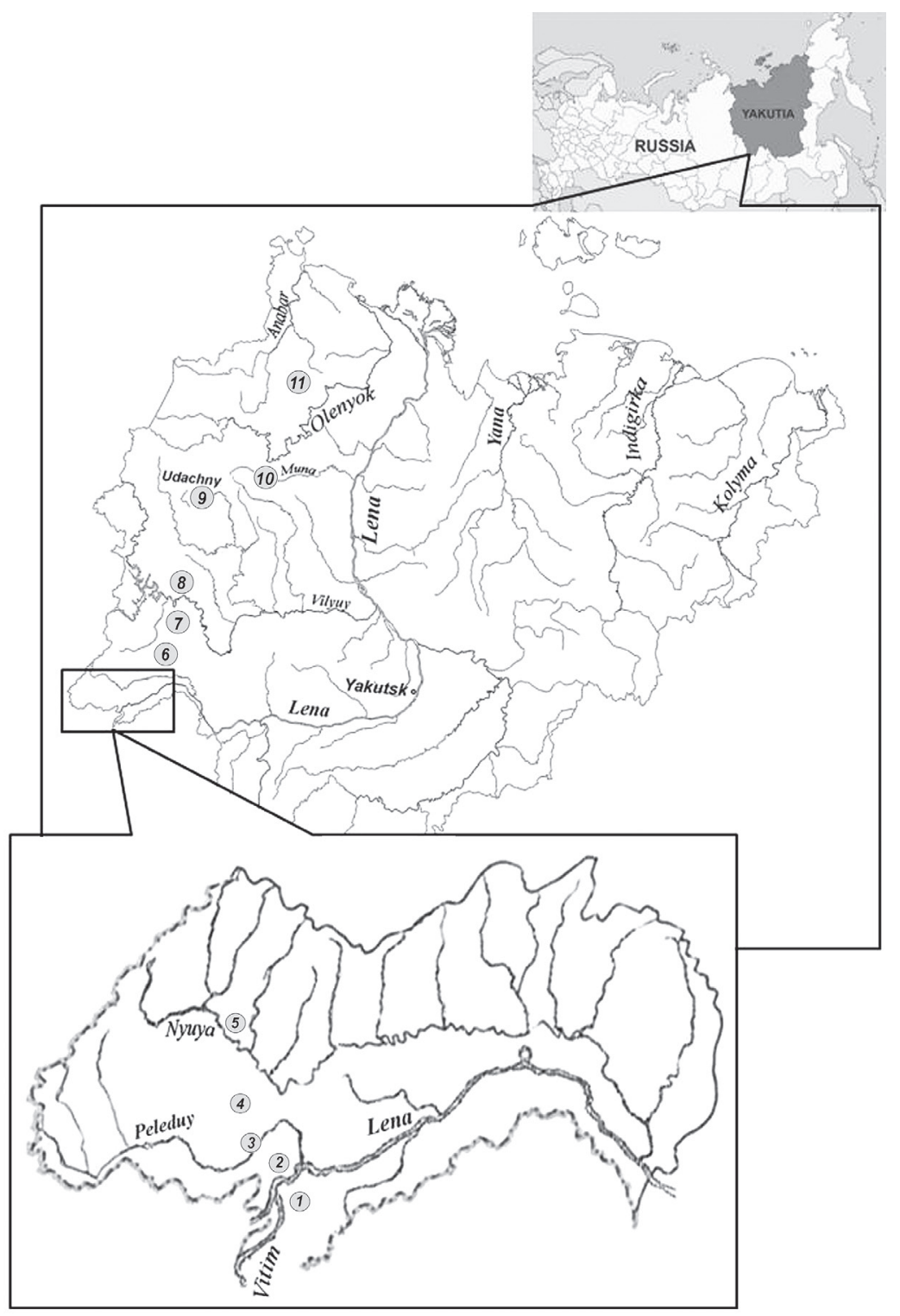

Fig. 1. Small mammal collection sites in the West Yakutia. 


\section{Results and discussion}

As our materials show, the fauna of small mammals within the taiga zone of the West Yakutia includes 21 species and varies from 8 to 18 species in separate research sites (Table 2). Comparison of the fauna of the two banks of the Lena River at the mouth of the Vitim River showed an almost complete coincidence in the community composition (the Jaccard index of 94.4\%). The difference in the species richness is only in one species: on the right bank we did not find Neomys fodiens (Tables 2, 3), but it is rather likely that it inhabits both banks of the river, and its absence in the material collected on the right bank can be explained by random processes due to a very low abundance of the species on the periphery of the range. As we move north along the meridian, the fauna becomes poorer: in the Peleduy River valley the similarity of the fauna with the previous sites is already as low as $70 \%$ due to the absence of Sorex araneus, S. isodon and Neomys fodiens. The fauna of the Nyuya and Peleduy interriverine area is even poorer, and its composition differs from that of the Lena River by $50 \%$, and the similarity with the Peleduy River valley is $75 \%$. Moving from the interriverine area to the Nyuya River valley, one more species (Sorex minutus) disappears, and to the north from there it is no longer registered; apparently, approximately there lies the northern boundary of the species range. It should be noted that the fauna of the left bank of the Nuya River is more similar to that of the Peleduy River valley than with the interriverine area. In the next site, Tas-Uryakh, Talpa altaica reappears after not being registered in the valleys of the Nyuya and Peleduy Rivers and between them (Shadrina, 2004), although it should be noted that this is the northernmost of the reliably known locations of the mole in Yakutia, whose stable colonies are described only in the Lena River valley. It is quite possible that the findings of the mole there have an element of chance, since they fall on the zone of clumped distribution of the species. Further north from Tas-Uryakh towards the city of Mirny, the fauna stays more or less the same, except for the disappearance of the mole and appearance of two new species: Lasiopodomys gregalis and Alexandromys middendorffi; both species are herbivorous inhabitants of open biotopes, but the first species in Yakutia gravitates towards agro-landscapes and grasslands of the middle taiga and penetrates far to the north (Tavrovskij et al., 1971; Volpert \& Shadrina, 2002), and the second is a typical representative of the tundra fauna.

In the Vilyuy River valley the fauna becomes even poorer than in the Mirny site, Microtus agrestis and Alexandromys middendorffii are absent there. For the Middendorf's vole the site 7 seems to be the southern limit of distribution, and it is very possible that it is present in the Vilyuy River valley, and for the field

Table 2. Distribution of small mammals in the corridor of $112-116^{\circ} \mathrm{E}$ in Yakutia.

\begin{tabular}{|l|c|c|c|c|c|c|c|c|c|c|c|}
\hline \multirow{2}{*}{ Species } & \multicolumn{9}{|c|}{ Research cites } \\
\cline { 2 - 11 } & \multicolumn{1}{|c|}{1} & 2 & 3 & 4 & 5 & 6 & 7 & 8 & 9 & 10 & 11 \\
\hline Talpa altaica Nikolsky, 1883 & + & + & - & - & - & + & - & - & - & - & - \\
\hline Neomys fodiens (Pennant, 1771) & - & + & - & - & - & - & - & - & - & - & - \\
\hline Sorex araneus Linnaeus, 1758 & + & + & - & - & - & - & - & - & - & - & - \\
\hline Sorex tundrensis Merriam, 1900 & + & + & + & + & + & + & + & + & + & + & + \\
\hline Sorex daphaenodon Thomas, 1907 & + & + & + & + & + & + & + & + & + & - & - \\
\hline Sorex caecutiens Laxmann, 1785 & + & + & + & + & + & + & + & + & + & + & + \\
\hline Sorex isodon Turov, 1924 & + & + & - & - & - & - & - & - & - & - & - \\
\hline Sorex roboratus Hollister, 1913 & + & + & + & + & + & + & + & + & + & + & - \\
\hline Sorex minutissimus Zimmermann, 1780 & + & + & - & - & + & + & + & + & - & - & - \\
\hline Sorex minutus Linnaeus, 1766 & + & + & + & + & - & - & - & - & - & - & - \\
\hline Myopus schisticolor (Liljeborg, 1844) & + & + & + & + & + & + & + & + & + & + & + \\
\hline Lemmus sibiricus (Kerr, 1792) & - & - & - & - & - & - & - & - & - & - & + \\
\hline Craseomys rufocanus (Sundervall, 1846) & + & + & + & + & + & + & + & + & + & + & + \\
\hline Myodes rutilus (Pallas, 1779) & + & + & + & + & + & + & + & + & + & + & + \\
\hline Arvicola amphibius (Linnaeus, 1758) & + & + & - & - & - & + & + & + & - & - & - \\
\hline Lasiopodomys gregalis (Pallas, 1779) & - & - & - & - & - & - & + & + & - & - & - \\
\hline Alexandromys oeconomus (Pallas, 1776) & + & + & + & + & + & + & + & + & + & + & + \\
\hline Alexandromys middendorffii (Poljakov, 1881) & - & - & - & - & - & - & + & - & + & + & + \\
\hline Microtus agrestis (Linnaeus, 1761) & + & + & + & - & + & + & + & - & - & - & - \\
\hline Micromys minutus (Pallas, 1771) & + & + & - & - & - & + & + & + & - & + & - \\
\hline Apodemus peninsulae (Thomas, 1907) & + & + & + & - & + & + & - & + & - & - & - \\
\hline Species found, total & 17 & 18 & 12 & 9 & 11 & 14 & 14 & 13 & 9 & 9 & 8 \\
\hline
\end{tabular}


Table 3. The similarity index of the fauna of small mammals (Jaccard index) in the studied sites.

\begin{tabular}{|c|c|c|c|c|c|c|c|c|c|c|c|}
\hline Sites & 1 & 2 & 3 & 4 & 5 & 6 & 7 & 8 & 9 & 10 & 11 \\
\hline 1 & & & & & & & & & & & \\
\hline 2 & 94.4 & & & & & & & & & & \\
\hline 3 & 70.6 & 66.7 & & & & & & & & & \\
\hline 4 & 52.9 & 50.0 & 75.0 & & & & & & & & \\
\hline 5 & 64.7 & 61.1 & 91.7 & 66.7 & & & & & & & \\
\hline 6 & 82.4 & 77.8 & 73.3 & 53.3 & 78.6 & & & & & & \\
\hline 7 & 63.2 & 60.0 & 62.5 & 53.3 & 66.7 & 75.0 & & & & & \\
\hline 8 & 66.7 & 63.1 & 66.7 & 57.1 & 71.4 & 80.0 & 80.0 & & & & \\
\hline 9 & 50.0 & 47.4 & 61.5 & 80.0 & 66.7 & 53.3 & 64.3 & 57.1 & & & \\
\hline 10 & 44.4 & 42.1 & 50.0 & 63.6 & 53.8 & 53.3 & 64.3 & 57.1 & 80.0 & & \\
\hline 11 & 31.6 & 30.0 & 40.0 & 54.5 & 46.2 & 37.5 & 37.5 & 40.0 & 70.0 & 70.0 & \\
\hline
\end{tabular}

vole near the Mirny area lays the northern boundary of its range.

The fauna of the site 9, Udachny, is represented by only nine species, and the similarity with the Vilyuy River valley is only $57 \%$. This is where a sharp decline in fauna richness occurs: on the whole, in the stretch Mirny - Udachny six species of small mammals disappear, including Micromys minutus, which was registered by Mordosov (1997) in the vicinity of the village Eyik $\left(66^{\circ} 01^{\prime} \mathrm{N}, 117^{\circ} 23^{\prime} \mathrm{E}\right)$. It should be noted that the Eurasian harvest mouse was found in 2018 in the Muna River valley (site 10) by Vas.A. Danilov.

Moving further to the north, the rate of decrease of species richness becomes lower, the similarity between the points Muna and Udachny reaches $80 \%$, and at the northernmost $\mathrm{s}$ of our research, in the site 11 (Olenyok and Anabar interriverine area), the similarity with the two nearest southward sites is $70 \%$. There a new species appears, a typical representative of the tundra zone, Lemmus sibiricus, and the fauna of small mammals is represented by only eight species, two of them belong to the tundra complex, and six are the most widespread species of the taiga zone of Yakutia that are abundant throughout the examined stretch of the meridian: two species of the wood voles (Myodes rutilus and Craseomys rufocanus), two shrew species (Sorex tundrensis and S. caecutiens), Myopus schisticolor and Alexandromys oeconomus.

The dendrogram plotted by fauna similarity (Fig. 2) reflects not only changes in the fauna when moving north, but also the heterogeneity in the group distribution in geomorphological units (river valleys and watersheds). The two southernmost sites, confined to the valleys of the Lena and Vitim rivers, are sharply distinct from the others; these sites are located in the southern periphery of the middle taiga subzone, the border with the south taiga forests. The communities of the middle taiga subzone (the valleys of the Peleduy and Vilyuy Rivers and the watersheds, sites 3-8) fall into several groups: the relatively rich in species Taas-Uryakh and Mirny sites show similarities with the southernmost sites of our study; this may be due to the relatively higher diversity of biotopes in these two sites. The third group with a high degree of similarity is formed by the sites in the river valleys of the Nuja, Peleduy and Vilyuy, although geographically the first two sites are very distant from Vilyuy. An isolated and very heterogeneous cluster is formed by the communities of the north taiga subzone (sites 9-11) and the Nyuya and Peleduy interriverine area.

When comparing the fauna by in the studied sites, one notices the uneven decline in species richness: as a rule, it is higher in the valleys of large rivers and in vicinity of human settlements than in watershed areas. Besides, the limited penetration of taiga species into the North in Yakutia, even in comparison with the neighboring regions, is conspicuous. For example, on the territory of Taimyr, most small mammal species penetrate much farther to the north (Litvinov, 1987) than in the West Yakutia (Volpert \& Danilov, 2017). The most likely reason for this phenomenon is climatic conditions, because physical barriers do not limit the distribution of small mammals in the studied region, as was shown above. As far as is known, the largest river in the considered transect, Vilyuy, does not present a barrier to the distribution of small mammals (Revin \& Germogenov, 1979). The fact that climate has a greater effect on the species richness of vertebrates than the heterogeneity of habitats has been previously pointed out by other authors (Moreno-Rueda \& Pizarro, 2009).

To clarify the role of climatic factors in the distribution of small mammals, we calculated the correlation of the species richness of communities with the following climatic indicators: winter duration, the average temperature in January, the average temperature in July, the average annual temperature, winter and summer precipitation, and annual precipitation (Table 4). The climatic parameters are given according to the data of the weather stations located near six sites of our study. The closest correlation of the species number was found 


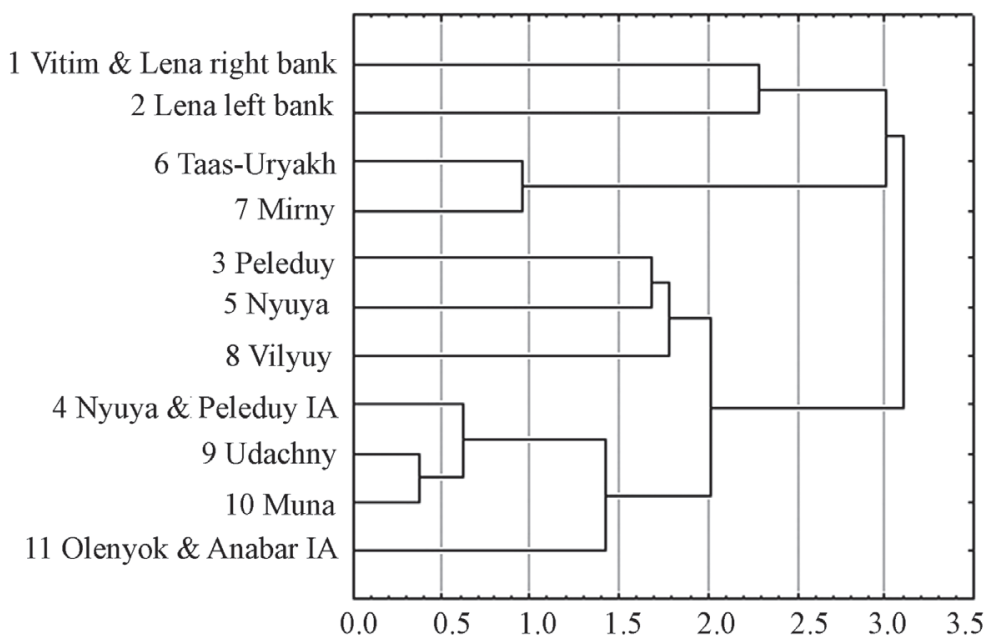

Fig. 2. The similarity of the small mammal fauna in the West Yakutia taiga zone.

with the precipitation in the winter period $(0.83, p<0.02)$; with lesser significance $(p<0.04)$ and a negative value it correlated with the winter duration $(-0.83)$, average July temperature and average annual temperature (0.83). Similar results in terms of climatic parameters were obtained by other researchers. For example, Qian et al. (2009) note that the gradient of beta-diversity of North American mammals corresponds to the gradients of decrease in average annual temperature and of increase in seasonality from south to north: beta-diversity is higher for areas with a higher average annual temperature, lower seasonality of temperature, and greater topographic complexity. In addition, a decrease in plant diversity may be an additional factor influencing the gradient of mammal species richness (Andrews \& O’Brien, 2000).

\section{Conclusion}

Thus, the species richness of small mammal fauna in the North-East Asia in the absence of physical barriers is primarily affected by winter precipitation, duration of the cold season, and temperature: the average annual temperature and that of the warmest period (July). In fact, it is these parameters that have a decisive role in the life of small mammals. While the significance of the depth of snow cover (which determines the microclimate in the habitats of small mammals in winter), the duration of winter, and average annual temperature are evident, the value of July temperature is less clear. It is possible that this factor regulates the ripening of berries and seeds and development of insects, i.e. affects small mammals through the availability of high-calorie food.

Thus, the decrease in species richness in the direction from south to north is uneven: in the river valleys, as a rule, the species richness is higher than in watersheds. The penetration of taiga species to the north has a larger scale than that of tundra species into taiga habitats; so changes in beta-diversity there occur mainly due to limits to the distribution of boreal species. Besides, in the absence of geographic barriers, a sharp decline in species richness is observed between $65^{\circ}$ and $66^{\circ} \mathrm{N}$, which coincides with the boundary between the middle-taiga and north-taiga subzones. Out of the climatic factors, the main limiting factor is winter precipitation, the duration of winter, the average July temperature, and average annual temperature, at the same time, no influence of such factors as January temperature and summer precipitation has been found.

Table 4. Correlations of the species richness of small mammal fauna with some climatic parameters of the West Yakutia.

\begin{tabular}{|l|c|c|c|}
\hline \multicolumn{1}{|c|}{ Climatic parameters } & Spearman's rho & $\mathrm{t}(\mathrm{n}-2)$ & Significance level \\
\hline Fauna \& winter duration & -0.83 & -2.96 & 0.04 \\
\hline Fauna \& January temperature & 0.77 & 2.42 & 0.07 \\
\hline Fauna \& July temperature & 0.83 & 2.96 & 0.04 \\
\hline Fauna \& average annual temperature & 0.83 & 2.96 & 0.04 \\
\hline Fauna \& winter precipitation & 0.89 & 3.82 & 0.02 \\
\hline Fauna \& summer precipitation & 0.77 & 2.42 & 0.07 \\
\hline
\end{tabular}


ACKNOWLEDGMENTS. The work was supported by the Russian Foundation for Humanities, project No. 17-402-00214, the state assignment of the Ministry of Education and Science of the Russian Federation No. 5.8169.2017/8.9 and the state assignment No. AAAA-A17-117020110058-4 "The structure and dynamics of populations and animal communities of the cold region of the North-East of Russia in the current conditions of global climate change and anthropogenic transformation of northern ecosystems: factors, mechanisms, adaptations, conservation", Institute for Biological Problems of Cryolithozone, SB RAS. We are grateful to our colleagues Dr. Vit.A. Danilov, Dr. D. Ya. Shadrin, Dr. M.M. Sidorov, Vas. A Danilov, and students N.I. Belolyubskaya, N.I. Smetanina, A.A. Alekseeva, M.N. Nikolaev, and A.A. Timofeev for their participation in collecting the materials. We are grateful to the referees for their valuable comments on an earlier draft of this manuscript.

\section{References}

Andrews P. \& O'Brien E.M. 2000. Climate, vegetation, and predictable gradients in mammal species richness in southern Africa // Journal of Zoology. Vol.251. P.205-231.

Brodie J.F. 2019. Environmental limits to mammal diversity vary with latitude and global temperature // Ecology Letters. Vol.22. No.3. P.480-485.

Buckley L.B., Davies T.J., Ackerly D.D., Kraft N.J.B., Harrison S.P., Anacker B.L., Cornell H.V., Damschen E.I., Grytnes J.-A., Hawkins B.A., McCain C.M., Stephens P.R. \& Wiens J.J. 2010. Phylogeny, niche conservatism and the latitudinal diversity gradient in mammals // Proceedings of the Royal Society, B. Vol.277. P.2131-2138.

Fergnani P.N. \& Ruggiero A. 2015. Ecological diversity in South American mammals: their geographical distribution shows variable associations with phylogenetic diversity and does not follow the latitudinal richness gradient // PLoS ONE. Vol.10. e0128264.

Fergnani P.N. \& Ruggiero A. 2017. The latitudinal diversity gradient in South American mammals revisited using a regional analysis approach: The importance of climate at extra-tropical latitudes and history towards the tropics // PLoS ONE. Vol.12 (9). e0184057.

Fraser D., Hassall C., Gorelick R. \& Rybczynski N. 2014. Mean annual precipitation explains spatiotemporal patterns of Cenozoic mammal beta diversity and latitudinal diversity gradients in North America// PLoS ONE. Vol.9 (9). e106499.

Karaseva E.V. \& Telitsyna A.Yu. 1995. [Methods of studying rodents in the field]. Moscow: Nauka. 226 p. [In Russian].

Kerr J. \& Packer L. 1998. The impact of climate change on mammal diversity in Canada // Environmental Monitoring and Assessment. Vol.49. P.263-270.

Krivosheev V.G. 1973. [Zoogeographical description of the mammalian fauna of Yakutia] // Yudin B.S. (ed.). Fauna Sibiri. Novosibirsk: Nauka. P.338-371 [in Russian].

Kucheruk V.V. 1963. [New methods of census taking of rodent pests and shrews] // Formozov A.N. \& Isakov Yu.A. (eds.). Organizatsiya i metody ucheta ptits i vrednykh gryzunov. Moscow: Izdatelstvo Akademii nauk SSSR. P.159-183 [in Russian].
Kullberg P. \& Moilanen A. 2014. How do recent spatial biodiversity analyses support the convention on biological diversity in the expansion of the global conservation area network? // Natureza \& Conservação. Brazilian Journal of Nature Conservation. Vol.12. No.1. P.3-10.

Lamanna C., Blonder B., Violle C., Kraft N.J.B., Sandel B., Š́mová I., Donoghue II C.B., Svenning J-C., McGill B.J., Boyle B., Buzzard V., Dolins S., Jørgensen P.M., Marcuse-Kubitza A., Morueta-Holme N., Peet R.K., Piel W.H., Regetz J., Schildhauer M., Spencer N., Thiers B., Wiser S.K. \& Enquist B.J. 2014. Functional trait space and the latitudinal diversity gradient // Proceedings of the National Academy of Sciences of the USA. Vol.111. P.13745-13750.

Litvinov Yu.N. 1987. [The population of small mammals at the northern boundary of their range in Taimyr] // Yudin B.S. (ed.). Fauna, taksonomiya, ekologiya mlekopitayushchikh i ptits. Novosibirsk: Nauka. P.11-16 [in Russian].

Mordosov I.I. 1997. [Mammals of the Western Yakutia]. Yakutsk: Knizhnoe Izdatel'stvo. 235 p. [In Russian].

Mordosov I.I. 2014. [Development and the current distribution of the mammalian fauna of Yakutia] // Vestnik SVFU. Vol.11. No.5. P.31-41 [in Russian].

Mordosov I.I. \& Vinokurov V.N. 1980. [Faunistic complexes of mammals in the taiga regions of the West Yakutia] // Mordosov I.I. (ed.). Fauna i ekologiya nazemnykh pozvonochnykh taezhnoi Yakutii. Yakutsk: Izdatel'stvo Yakutskogo Gosudarstvennogo Universiteta. P.57-65 [in Russian].

Moreno-Rueda G. \& Pizarro M. 2009. Relative influence of habitat heterogeneity, climate, human disturbance, and spatial structure on vertebrate species richness in Spain // Ecological Research. Vol.24. No.2. P.335-344.

Murphy D.D. \& Weiss S.B. 1992. Effects of climate change on biological diversity in Western North America: Species losses and mechanisms // Peters R.L. \& Lovejoy T.E. (eds.). Global Warming and biological diversity. New Haven: Yale University Press. P.355-368.

Obolenskaya E.V. \& Lissovsky A.A. 2015. Regional zoogeographical zoning using species distribution modelling by the example of small mammals of South-Eastern Transbaikalia // Russian Journal of Theriology. Vol.14. No.2. P.171-185.

Odum E.P. 1983. Basic ecology. Philadelphia: Saunders College Pub. 613 p.

Oliveira B.F., Machac A., Costa G.C., Brooks T.M., Davidson A.D., Rondinini C. \& Graham C.H. 2016. Species and functional diversity accumulate differently in mammals // Global Ecology and Biogeography. Vol.25. No.9. P.1119-1130.

Pereira H.M., Leadley P.W., Proença V. et al. 2010. Scenarios for global biodiversity in the 21st century// Science. Vol.30. No.6010. P.1496-1501.

Pianka E.R. 1966. Latitudinal gradients in species diversity: a review of concepts // American Naturalist. Vol.100. P.33-46.

Pianka E.R. 1978. Evolutionary ecology. New York: Harper and Row Publishers. 397 p.

Qian H., Badgley C. \& Fox D.L. 2009. The latitudinal gradient of beta diversity in relation to climate and topography for mammals in North America // Global Ecology and Biogeography. Vol.18. No.1. P.111-122.

Revin Yu.V. \& Germogenov N.I. 1979. [The population of terrestrial vertebrates and its possible changes in vicinity 
of the reservoir of the Vilyuy hydropower plant III] // Popov M.V., Kirillov F.N. \& Vozin V.F. (eds.). Okhrana i ratsional'noe ispol'zovanie zhivotnogo mira i prirodnoi sredy Yakutii. Materialy VII Respublikanskogo soveshchaniya po okhrane prirody Yakutii. Yakutsk: Yakutskoe Knizhnoe Izdatel'stvo. P.32-39 [in Russian].

Rohde K. 1992. Latitudinal gradients in species diversity: the search for the primary cause // Oikos. Vol.65. P.514-527.

Sapogov A.V. 1983. [Zonal specifics of the population of mouse-like rodents of the Yenisei taiga] // Syroechkovskii V.E. (ed.). Zhivotnyi mir eniseiskoi taigi i lesotundry. Moscow: Nauka. P.204-215. [In Russian].

Schemske D.W. \& Mittelbach G.G. 2017. "Latitudinal gradients in species diversity": Reflections on Pianka's 1966 article and a look forward // American Naturalist. Vol.189. P.599-603.

Shadrina E.G. 2004. [New data about dispersal of the Siberian mole Talpa (Asiascalops) altaica on the east-north of it's areal] // Zoologicheskii Zhurnal. Vol.83. No.4. P.508-509 [in Russian, with English summary].

Shchipanov N.A., Kouptsov A.V., Kalinin A.A., Demidova T.B., Lyapina M.G., Aleksandrov D.Y., Raspopova A.A., Pavlova S.V., Tumasyan P.A. \& Oleinichenko V.Y. 2010. Small mammals of the southeast Tver Oblast. Communication 1 . The fauna and biotopic distribution // Contemporary Problems of Ecology. Vol.3. No.5. P.587-592.

Sheftel B.I. 1983. [Zonal specifics of the population of insectivorous mammals of the Yenisei taiga and for- est-tundra] // Syroechkovskii V.E. (ed.). Zhivotnyi mir eniseiskoi taigi i lesotundry. Moscow: Nauka. P.184-203 [in Russian].

Tavrovskij V.A., Egorov O.V., Krivosheev V.G., Popov M.V. \& Labutin Yu.V. 1971. [Mammals of Yakutia]. Moscow: Nauka. 660 p. [In Russian].

Urban M.C. 2015. Accelerating extinction risk from climate change // Science. Vol.348. No.6234. P.571-573.

Volpert Ya.L. \& Danilov V.A. 2017. [Population of small mammals of the Anabar and Olenyok interriverine area] // Vestnik Irkutskoi Gosudarstvennoi Sel'skokhozyaistvennoi Akademii. Vol.83. P.17-24 [in Russian].

Volpert Ya.L. \& Shadrina E.G. 2002. [Small mammals of the North-East Siberia]. Novosibirsk: Nauka. 246 p. [In Russian].

Volpert Ya.L. \& Yudin B.S. 1986. [Spatial changes in faunistic complexes of small mammals of Yakutia] // Yudin B.S. (ed.). Okhotnichie-promyslovye resursy Sibiri. Novosibirsk: Nauka. P.198-202 [in Russian].

Willig M.R. \& Presley S.J. 2018. Latitudinal gradients of biodiversity: theory and empirical patterns // Della Sala D.A. \& Goldstein M.I. (eds.) The Encyclopedia of the Anthropocene. Oxford: Elsevier. Vol.3. P.13-19.

Willig M.R., Kaufman D.M. \& Stevens R.D. 2003. Latitudinal gradients of biodiversity: pattern, process, scale, and synthesis // Annual Review of Ecology Evolution and Systematics. Vol.20. No.34. P.273-309. 